\title{
Do historical maps show the maximal anthropopressure in the Carpathians?
}

\author{
Michał SobALA iD https://orcid.org/oooo-0002-1870-8096; e-mail: michal.sobala@us.edu.pl \\ University of Silesia, Faculty of Natural Sciences, 6 o Będzińska str., Sosnowiec 41-20o, Poland
}

Citation: Sobala M (2021) Do historical maps show the maximal anthropopressure in the Carpathians?. Journal of Mountain Science 18(8). https://doi.org/10.1007/s11629-021-6680-z

(C) The Author(s) 2021.

\begin{abstract}
Many landscapes bear the marks of historical land use. These marks can be the basis for a reconstruction of a historical land use structure as some of them are typical of different types of human activity. The aim of this paper is to determine whether Austrian cadastral maps from the 19th century present the image of the most transformed environment in the Western Carpathians as a result of agricultural activity. Land use structure and terrain forms were detected based on Austrian cadastral maps from 1848, airborne laser scanning and field studies. In two of the test areas, the percentage of arable fields was higher among the plots with stone mounds than the percentage among the plots without them. In the third test area, the relationship was reversed. Also, lynchets, terraces and stone walls sometimes occur in plots that were not arable fields in 1848. Thus, the Austrian cadastral maps from 1848 could not reflect the maximal range of arable fields in the Carpathians in the 19th century. However, it is impossible to determine the historical structure of land use precisely. Nevertheless, an inventory of terrain forms can be used to assess land use when historical maps have not preserved or when available maps do not present land use in detail.
\end{abstract}

Keywords: Land abandonment; Historical land use; Airborne laser scanning; Anthropogenic landforms; Stone mounds; Stone walls

Received: 12-Jan-2021

Revised: 21-Apr-2021

Accepted: 14-May-2021

\section{Introduction}

Many landscapes bear the marks of historical land use worldwide (DeFries et al. 2004; Myga-Piątek 2015). Abandoned areas preserve traces of former human activity for a long time as they have not been transformed in the course of further use (Wolski 2009). The effects of past land use are visible in the landscape (Munteanu et al. 2015) and can persist for decades (Wallin et al. 1994) or even centuries (Boucher et al. 2013; Thompson et al. 2013). These traces in abandoned mountain areas include different terrain forms and object and were a subject of studies conducted among others in New England (Johnson and Ouimet 2016), Italy (Manenti 2014), Ireland (Hollingsworth and Collier 2020), Czech Republic (Duchoslav 2002) and Poland (Wolski 2016; Duma et al. 2020). These terrain forms and objects can be treated as an indicator of former land use. Thus, they can be the basis for a reconstruction of a historical land use structure as some of them are typical of different types of human activity. The forms that are typical of land cultivation include terraces, lynchets, stone walls and mounds. A terrace is a piece of sloped plane that has been cut into a series of successively receding flat surfaces or platforms, which resemble steps, for the purposes of more effective farming (Tarolli et al. 2014). A lynchet is a boundary between neighbouring plots perpendicular to contour lines and made of ploughed, fine rock material. When there was a lot of this rock material, stone walls were developed 
(Duma et al. 2020). In some cases, this material was laid in stone mounds located on the plot boundaries or even within plots (Latocha et al. 2019). On the other hand, the only forms typical of mountain grazing that have survived are a few small hollows, usually oval, formed by shepherds due to the deepening of natural springs or bog springs (Wolski 2016). This different origin of the anthropogenic forms makes it possible to distinguish varying land types based on them.

Research on changes in land use over time has so far been based mainly on archival cartographic materials. Although the basic principle of this type of analysis is the use of information sources for verification, such as archival research, vegetation and soil research etc., these sources have not been used on a large scale so far, and archival maps remain the primary source of information (Yang et al. 2014). This is because only maps can be referenced to specific locations to make measurement possible (Nieścioruk 2013). On the other hand, the multidisciplinary research helps make the assessment of land use more credible (Machar et al. 2017).

Among all the available historical cartographic materials, cadastral maps are the best because they are the most accurate data source (Fojert et al. 2020). The availability of cadastral maps and their processing in land use studies, land tenure reconstructions and various landscape and ecological research, ranges from regions in Germany, Italy, Nordic countries, and Central Europe to the USA (Bender et al. 2005; Agnoletti 2007; Hamre et al. 2007; Bič́k et al. 2001; Kein and Baigent 1994). In Central Europe, Franziscean (Stable) Cadastre is a representative example of the information-rich old cadastral apparatus that stands as a source of significant importance for land-use change research (Forejt et al. 2020). The cadastre was produced for the former Austrian Empire between the year 1817 and the 1880 s and covers at least partly the contemporary area of Czechia, Slovakia, Austria, Poland, Slovenia, Hungary, Ukraine, Croatia, Romania, Bosnia, and Serbia (Feucht 2008). Due to its indisputably wide spatial extent and variety of spatial and non-spatial information, this particular data source is attracting increasing attention for a variety of purposes ranging from the research of LULC change through the reconstruction of river channels or slope movements and loss or persistency of particular land use classes to localisation of abandoned settlements and mining sites (Dolejš and Forejt 2019). The demands of land administration and tax collection also challenged the accuracy of land surveys to improve significantly (Forejt et al. 2018).

Nevertheless, it should be emphasised that archival maps refer to a single time section in the past, which contrasts with the dynamically evolving landscape (Yang et al. 2014). Hence, maps do not show information on land use between particular time sections presented on consecutive maps. Thus, the course of land use changes between consecutive time sections can only be interpreted, which is associated with uncertainty as to the correctness of inference (Wolski 2012). The second problem in the analysis of land-use changes is connected with the detail of the maps. Archival maps analysis to infer land use is subject to uncertainties as the quality of recognition depends on the expertise in map interpretation and visual perception (Brus et al. 2018). Uncertainty is a crucial aspect of a proper map processing effort aiming at land use changes analysis (Leyk et al. 2005; Kaim et al. 2014). Not all historical maps contain information about land use, but sometimes only land cover information. Furthermore, these data are of a very general level (e.g., they distinguish only forest and non-forest areas), making it impossible to analyse the changes in land use in detail (Sobala et al. 2017). In such a case, it is necessary to look for other, supplementary data that can be used to verify the content of the archival maps (Plit 2006). Moreover, such additional data may enable the reconstruction of land use over time that is not represented on the map or in areas for which archival maps have not been preserved. This article covers areas for which archival maps have been preserved partially, but it is uncertain whether they represent the maximal range of historical agricultural land use.

Forest range has been increasing slowly since the 19th century in many developed countries. This increase has been a clear reversal of forest cover trends in the previous period of dominant deforestation, referred to as the forest transition (Mather 1992; Mather and Needle 1998). From the 19th century, agricultural land was abandoned or purposefully converted to forests, reflecting the economic and social development of societies, changing population pressures, and national policies attempting to overcome the scarcity of forest products (Kozak 2010). These factors concern primarily the use of areas with unfavourable conditions or position in 
relation to outlets (Mather and Needle 1998). Therefore, the increase in forest range may be the fastest in the mountains (especially in the highest parts), due to their often marginal location on a national scale and natural conditions which are difficult for agriculture. The processes of settlement and agricultural expansion arrive in the mountains last. Simultaneously, the reverse occurs first, before such changes are felt on a national or continental scale (Kozak 2004). As a result, landscapes of many mountain areas in developed countries were the most anthropogenically transformed in the 19th century as the highest parts of mountain areas were utilised.

One example of a mountain area where forest transition occurred is the Carpathians (Kozak 2010). Research on changes in forest cover in the Carpathians has been conducted in Romania (Kucsicsa and Dumitrică 2019), Slovakia (Feranec and Ot'ahel' 2008), Ukraine (Baumann et al. 2011), Hungary (Biró et al. 2012) and Poland (Kozak et al. 2018). These studies were based on archival cartographical materials, and aerial and satellite images. They focused mainly on changes in forest range and concern large areas, sometimes even the whole arc of the Carpathians (Munteanu et al. 2014). Only a few studies have been conducted based on large scale cadastral materials from the 19th century, which addressed detailed LULC changes in the Polish Carpathians (Harvey et al. 2014; Bucała-Hrabia 2017; Kijowska-Strugała et al. 2018; Sobala et al. 2017). Only some of them concern terrain studies that aim to verify archival maps (Sobala and Rahmonov 2020). Generally, land use and land cover studies in the Carpathians mainly cover only the minimal range of forests in this area and do not analyse in detail the importance of agricultural land use structure for landscape transformation. Although land use in the 19th century in the Carpathians has sometimes been analysed based on cadastral maps (Wolski 2007), these studies did not indicate whether the cartographic sources illustrate the most transformed landscape in historical times.

The aim of this paper is to determine whether Austrian cadastral maps from the 19th century present the image of the most transformed environment in the Western Carpathians as a result of agricultural activity. The most transformed environment means the most deforestation and the utilisation of mid-forest glades for land cultivation. This study is an attempt to indicate whether the degree of transformation of the environment connected with land cultivation in the 19th century was greater than the land use visible on cadastral maps from this period. As far as agricultural activity is concerned, it is land cultivation that contributes most to the transformation of the environment. It is a significant factor affecting erosion processes. Increased soil erosion rates are directly associated with nutrient loss, which may reduce agricultural productivity (Bakker et al. 2007) and cause the eutrophication of water bodies (Istvánovics 2009). In some cases, advanced soil erosion stages, such as rill and gully erosion, can devastate entire areas, making them unusable for agricultural purposes (Kirkby and Bracken 2009). As mentioned above, land cultivation retains traces such as terrain forms that were detected, among others, in the Carpathians (Kroczak et al. 2018). Contrary to land cultivation, mountain grazing has a smaller impact on the mountains' natural environment. Although overgrazing in some cases can cause negative results in an environment (Niu et al. 2019), mountain grazing is a suitable way of using mountain land. It should be the dominant type of agricultural activity in such areas (FAO 2013).

It must be emphasised that the maximal range of deforestation in the Western Carpathians connected with agricultural activity fell in the mid-19th century (Kozak 2010). This was connected with the so-called "land hunger" phenomena; overpopulation and poor economic conditions forced people to set arable fields at higher elevations and on sloping hills, although most sites were unsuitable for crops (Sobala et al. 2017).

\section{Study Area}

The Carpathians form a major mountain arc in Europe, encompassing the Hungarian lowlands and forming a vast curve that stretches from the Danube close to Vienna to the Danube again between Romania and Serbia (Fig. 1). The area of the region exceeds 200,000 km² (Kondracki 1989). The Western Carpathians stretch from the Low Beskids range of the Eastern Carpathians along the border of Poland with Slovakia toward the Moravian region of the Czech Republic and the Austrian Weinviertel. This area comprises about $70,000 \mathrm{~km}^{2}$. The highest elevation is the Gerlachovský štít (2655 m asl.), located in the Tatra Mountains. However, besides the 


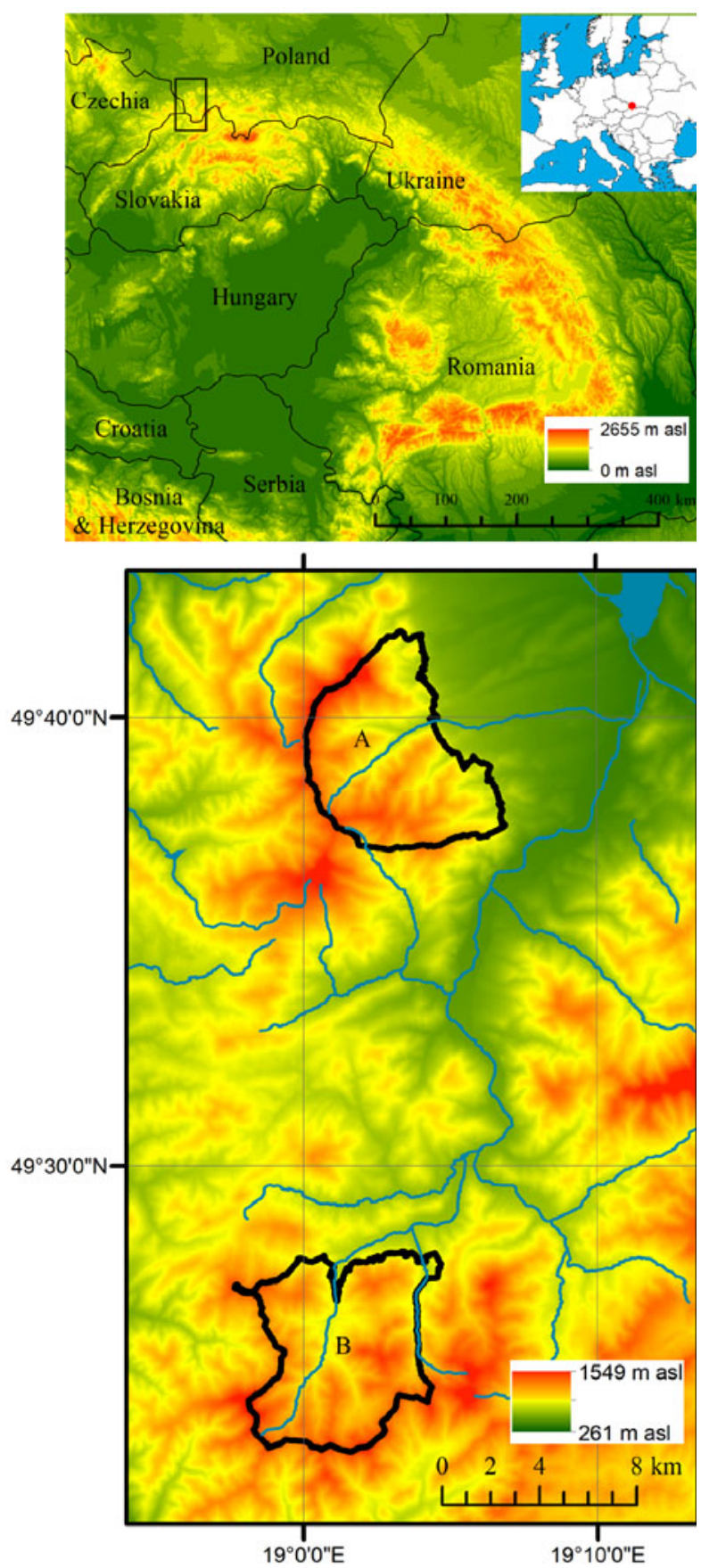

Fig. 1 Study area. A -Barania Góra Range, B -Wielka Racza Range.

region of the Tatra Mountains, this mountain belt covers areas of mid- and low-mountains, foothills and valley bottoms (Kozak et al. 2013).

The Western Carpathians have been relatively densely populated since the Middle Ages. At the turn of the 15th and 16th centuries, Vlachs shepherds came to this area, founding new settlements at higher elevations and forming glades by slashing and burning the forest for sheep to graze (Jawor 2000). For this reason, humans have exerted a strong influence on land use and land cover in the highest parts of these mountain belts, leading to landscape opening. From the end of the 17th century until the mid-19th century, the expansion of buildings, meadows, pasturelands and arable fields occurred. As a result, settlements developed on some of the glades (Broda 1956). In the mid-19th century, mountain grazing started to collapse as a result of industrial development and the intensification of forest management connected with the Industrial Revolution. The abolition of serfdom and the stagnation in the sale of sheep products also had an influence. All these factors stimulated the afforestation of some mountain pastures and glades by the second half of the 19th century. However, in the whole Polish Carpathians, stabilisation of the forest area in the second half of the 19th century was quite a common phenomenon. Following this stage, the surface of mountain pastures and glades decreased. This process has continued up to the present day (Kozak 2010; Sobala 2018).

The detailed study was carried out in the Silesian Beskids and Żywiec-Kysuce Beskids (the Western Carpathians). Two areas were chosen in these mountain ranges for historical land use reconstruction based on a historical cadastral map: the part of the Barania Góra range and the part of the Wielka Racza range (Fig. 1). They each occupy $45 \mathrm{~km}^{2}$. The Barania Góra range is located in the eastern part of the Silesian Beskids, with an absolute altitude ranging from 516 to $1257 \mathrm{~m}$ asl. Areas situated between 700 and $1000 \mathrm{~m}$ asl. dominate (63\%). The maximal slope is $46^{\circ}$, whereas the average slope is $18.7^{\circ}$. The medium slope $\left(10^{\circ}-20^{\circ}\right)$ predominates, occupying $50 \%$ of this area. Gentle slopes $\left(<10^{\circ}\right)$ occupy only $8.2 \%$. The Wielka Racza range is located in the Żywiec-Kysuce Beskids, with an absolute altitude ranging from 595 to $1236 \mathrm{~m}$ asl. Areas located between 700 and $1000 \mathrm{~m}$ asl. dominate (78\%). The maximal slope is $54^{\circ}$, whereas the average slope is $17.8^{\circ}$. The medium slope predominates, occupying $53 \%$ of this area. Gentle slopes occupy only $10.7 \%$. These two areas were chosen as their location in higher parts of the Western Carpathians means that they were abandoned first and the phase of afforestation in the Carpathians started in this type of area (Sobala et al. 2017).

Considering the above-mentioned environmental 
Table 1 Characteristics of test areas

\begin{tabular}{|c|c|c|c|c|c|c|}
\hline \multirow[b]{2}{*}{ Test area } & \multirow[b]{2}{*}{ Geographical coordinates } & \multirow{2}{*}{$\begin{array}{l}\text { Altitude } \\
\text { (m asl) }\end{array}$} & \multicolumn{3}{|c|}{ Slope $\left(^{\circ}\right)$} & \multirow{2}{*}{$\begin{array}{l}\text { Dominant } \\
\text { aspect }\end{array}$} \\
\hline & & & Range & Mean & $\begin{array}{l}\text { Standard } \\
\text { deviation }\end{array}$ & \\
\hline A1 Radziechowska & $49^{\circ} 37^{\prime} 44^{\prime \prime N} ; 19^{\circ} \mathrm{O}^{\prime} 14^{\prime \prime} \mathrm{E}$ & $917-1044$ & $0.0-45.2$ & 14.6 & 6.3 & $\mathrm{~N}, \mathrm{~S}$ \\
\hline A2 Ostre & $49^{\circ} 39^{\prime} \mathrm{O} 1^{\prime \prime} \mathrm{N} ; 19^{\circ} \mathrm{O} 3^{\prime} 40^{\prime \prime} \mathrm{E}$ & $789-945$ & $0.0-45.0$ & 14.6 & 5.4 & SE \\
\hline A3 Slopes of Ostre & $49^{\circ} 39^{\prime} 10^{\prime \prime} \mathrm{N} ; 19^{\circ} \mathrm{O} 4^{\prime} 40^{\prime \prime} \mathrm{E}$ & $559-783$ & $0.1-53.2$ & 21.7 & 6.6 & $\mathrm{SE}$ \\
\hline B1 Praszywka & $49^{\circ} 27^{\prime} 19^{\prime \prime} \mathrm{N} ; 19^{\circ} \mathrm{O} 2^{\prime} 22^{\prime \prime E}$ & $810-1044$ & $0.1-44 \cdot 3$ & 17.0 & 4.5 & SE, N \\
\hline
\end{tabular}

conditions, both areas are characterized by unfavourable conditions to land cultivation, but there are appropriate conditions for grazing economy. This confirms the generally accepted view that mountain grazing should be the primary type of agricultural activity in the Western Carpathians (Kopeć 2000).

In turn, four test areas were chosen to reconstruct a historical land use based on airborne laser scanning and field studies (Table 1): the Praszywka (B1) in the Wielka Racza range and the Radziechowska (A1) and Ostre (A2), and the southeastern slopes of Ostre (A3) in the Barania Góra range. These test areas differ in terms of former land use structure and altitude. They were chosen as they were all abandoned and have remnants of former human activity preserved.

\section{Materials and Methods}

\subsection{Materials}

In this paper the following materials were used: Austrian cadastral maps from 1848 and a digital terrain model developed based on airborne laser scanning.

The Austrian cadastral map scaled at 1:2,880 was used to reconstruct the historical land use. The minimal mapping unit was 25 square fathoms, which is equal to approximately $90 \mathrm{~m}^{2}$ (Forejt et al. 2020). The digital terrain model used in this study is a product based on LiDAR scanning (airborne laser scanning ALS) with a density of $4-8$ points $/ \mathrm{m}^{2}$. It was made in a flat rectangular coordinate system 1992 with a $1 \mathrm{~m} \times 1 \mathrm{~m}$ resolution and an average height error in the range of $0.2 \mathrm{~m}$. LiDAR point clouds were acquired within the national ISOK (Informatyczny System Osłony Kraju) project. The data were collected in a multi-return mode with a maximum of five return echoes registered for each emitted pulse and a field of view of less than $\pm 25^{\circ}$. Secondly, the data were classified according to the American Society for Photogrammetry and Remote Sensing standards into ground (class 2), low (3), medium (4) and high (5) vegetation, buildings (6), low points (7), model keypoints (8), water (9) and others. This classification was performed automatically using the progressive densification filtering algorithm and subsequently followed by a visual inspection and manual correction of misclassified points (Meng et al. 2010). The preprocessed LiDAR data were received from GUGiK (Główny Urząd Geodezji i Kartografii; the Head Office of Geodesy and Cartography).

\subsection{Methods}

\subsubsection{Historical map analyses}

The research method used in this study consists of the following stages, which are shown in Fig. 2.

The analogue historical cadastral maps were scanned and, consequently, georeferenced in two steps, which consisted of: (i) calculating the transformation matrix and carrying out proper geometric transformation; (ii) interpolation resampling of a distorted image to a new raster of regular size ("rubbersheeting"). Such a two-step process allowed for higher georeferencing accuracy, which ensures the quality of the results obtained (Affek 2013). These maps were overlaid onto a grid with a size corresponding to the map frame size using affine transformation and the coordinates of the frame corners. Rectification was then carried out and its precision verified by estimating the root-meansquare error (RMSE), which was < 4.91m for each map sheet. Then, the historical local reference system was transformed into the contemporary, flat rectangular coordinate system 1992. This step involved the application of a simplified Helmert transformation with three parameters $(\mathrm{dx}, \mathrm{dy}, \mathrm{dz})$ of the shift in the coordinate system origin using the inverse Molodensky formulas (Affek 2013). Then, screen digitalization was conducted using the snapping method. Errors are usually generated during this operation, e.g., duplicating arcs, floating or short lines, overlapping lines, overshoots and undershoots, 


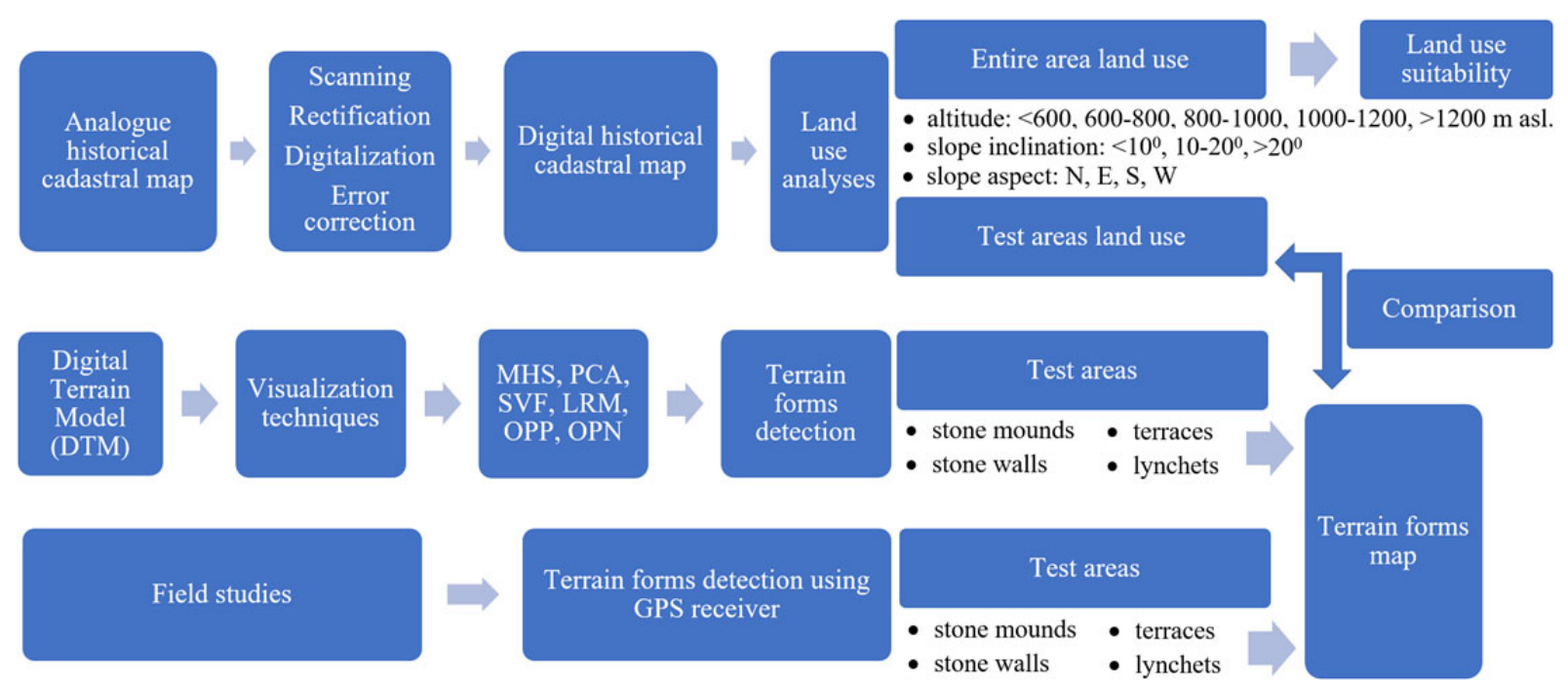

Fig. 2 Schematic diagram of the research procedure. MHS - multiple hill shading, PCA - principal component analysis, SVF - sky-view factor, LRM - local relief model, OPP - positive openness, OPN - negative openness.

unclosed and weird polygons (Maraş et al. 2010). A topology construction tool was used to detect and eliminate these errors. Screen digitization was combined with the creation of a database of land use and land cover forms.

Consequently, the land use analysis was conducted based on digitalized cadastral maps. The vector map prepared in this way was used to conduct detailed analyses of the historical land use in terms of altitude above sea level, slope inclination and aspect. The V_LATE add-on of the package ArcGIS $\AA$ ver. 10.8 was used, which allowed the landscape land use structure to be calculated. The land use structure analyses were conducted for the entire study areas and for four test areas. Analyses for the entire area allowed the relation between land used and topographical relief to be assessed. In turn, analyses for the test areas formed the basis for a comparison of land use structure with occurrence of terrain forms.

\subsubsection{Terrain forms detection}

The analyses of digital terrain model (DTM) were carried out simultaneously. This model was used to detect anthropogenic terrain forms connected with agricultural activity such as lynchets, terraces, stone walls and stone mounds. To improve the effectiveness of DTM interpretation, several visualization techniques were used: multiple hill shading (MHS), principal component analysis (PCA), sky-view factor (SVF), local relief model (LRM), positive openness (OPP) and negative openness (OPN) (Kokalj and Hesse 2017). Despite many visualization techniques, final detection and verification of anthropogenic terrain forms can only be performed directly during field studies (Affek 2016). Hence, the last stage of the studies was terrain inventory of these forms and verification of the results of the DTM interpretation. Primarily, the terrain inventory of stone mounds was conducted as it is impossible to distinguish them unambiguously based on DTM from other point objects such as branch piles (Affek 2014). The linear anthropogenic terrain forms detected based on DTM were verified during field studies. To this end, a GPS receiver GPSMAP®66i was used. Stone mounds as a point object were detected using point marking, whereas to detect linear forms, the LiveTrack tool was used. It must be emphasised that not all existing terrain forms can be clearly identified based on DTM visualisations. Similarly, without identifying these forms based on DTM visualisations, it would be difficult to recognize them during field studies. Due to secondary forest succession in abandoned glades, some of the forms are masked by vegetation, and reaching some parts of the glades is very difficult, sometimes even impossible.

\subsubsection{Comparison of range of arable fields and terrain forms}

Following the above-mentioned stages, the range of arable fields was compared with the occurrence of anthropogenic terrain forms. As far as stone mounds are concerned, data was analysed with an $\mathrm{R}$ 4.0.2 statistical package (R Core Team 2020). Exploratory analyses indicated a small number of occurrences of some of the plot types in the test areas. Thus, the dependent variable, plot type, was recoded into two 
categories: arable fields (AF) vs other types. Stone mounds as a predictor were also dichotomised to zero vs more than zero because the distribution was highly right-skewed, and zeros constituted 59\% of the observations. The distribution of the plot area was also highly right-skewed and in the remaining analyses it is always presented after logarithmic transformation.

Continuous variables are summarised with median $(\mathrm{Me})$ and inter quantile ranges and for the categorical variable counts and percentages are presented. To model the relationship between the dependent variable and predictors, a series of Bayesian logistic regression models were used. The best model was determined based on the leave-oneout information criterion (LOOIC), with lower LOOIC indicating a better model fit (Vehtari et al. 2017).

In Bayesian statistics, the inference is based on the posterior distributions of a parameter (e.g., regression weight). The posterior is usually summarised with a mean and $95 \%$ credible interval (95\% CI). If the 95\% CI excludes zero, the parameter value can be considered statistically credible. The models were fitted using brms package (Bürkner 2017). The prior for regression weight on logit scale was set to normal $(0,5)$, assuring uniform coverage of the probabilities. Six parallel chains with 4000 iterations (including 2000 for warmup) samples were used to approximate the posterior. To reduce autocorrelations in the resulting chains, every tenth iteration was recorded, resulting in 1200 recorded samples. The sampling procedure was efficient as it was evaluated with a visual inspection of the posteriors, chains, autocorrelations plots and R-hats $<1.01$.

Other terrain forms, such as terraces, lynchets and stone walls, were not statistically analysed as not all existing linear terrain forms can be clearly identified based on DTM and field verification (the reason for this has been explained above). Thus, in this case, only descriptive analyses were conducted.

\section{Results}

\subsection{Land use structure in 1848}

Both study areas are mainly covered with forests; however, the forests in the Barania Góra range cover a higher surface area than in the Wielka Racza range
(82\% and 69\%, respectively) (Fig. 3). These study areas are different in terms of their former agricultural use. The Barania Góra range was used mainly for mountain grazing and mowing (88\% of agricultural land), whereas the Wielka Racza range was used mainly for land cultivation $(68 \%$ of agricultural land). However, it must be emphasised that $57 \%$ of the agricultural land in the Wielka Racza range was used as alternate-fallow land.

In both study areas, arable fields also occurred above $1000 \mathrm{~m}$ asl. However, the higher the altitude, the lower the cover of arable fields. The share of surfaces used for land cultivation was higher in the higher parts of the Wielka Racza range than in the Barania Góra range. The slope inclination also influenced the land use structure as the gentler the slope, the more agricultural land occurred. Nevertheless, arable fields also occurred on steep slopes $\left(>20^{\circ}\right)$. The aspect did not influence the location of agricultural land.

All analysed glades located in the Barania Góra range were mainly covered with pastures and meadows (Fig. 4). In the A1 and A2 test areas, there were both pastures and meadows, whereas in A3, there were only pastures. Nevertheless, arable fields also occurred, constituting about $20 \%$ of the agricultural land in the $\mathrm{A} 2$ and $\mathrm{A}_{3}$ areas. There was only one small arable field in A1. Contrary to in the Barania Góra range, alternate-fallow lands dominated in the B1 test area located in the Wielka Racza range ( $87 \%$ of agricultural land) (Fig. 4).

\subsection{Relationship between arable fields and terrain forms}

1138 stone mounds and over 530 anthropogenic linear terrain forms and objects, such as terraces, lynchets, stone walls and remains of cart roads, were inventoried (Fig. 5). Stone mounds are located in three out of the four test areas: A2, A3 and B1 (Fig. 6)

Exploratory analyses indicated the complex relationship between plot type, stone mounds, plot area, and test area (Fig. 7). In the A2 test area, 13 out of 30 plots with stone mounds (43\%) were arable fields, whereas only 14 out of 56 plots without stone mounds (25\%) were arable fields. Similarly, in the B1 test area, the percentage of arable fields was higher among the plots with stone mounds (79/100, 79\%) than the percentage among the plots without stone mounds $(24 / 70,34 \%)$. In the A3 test area, the 

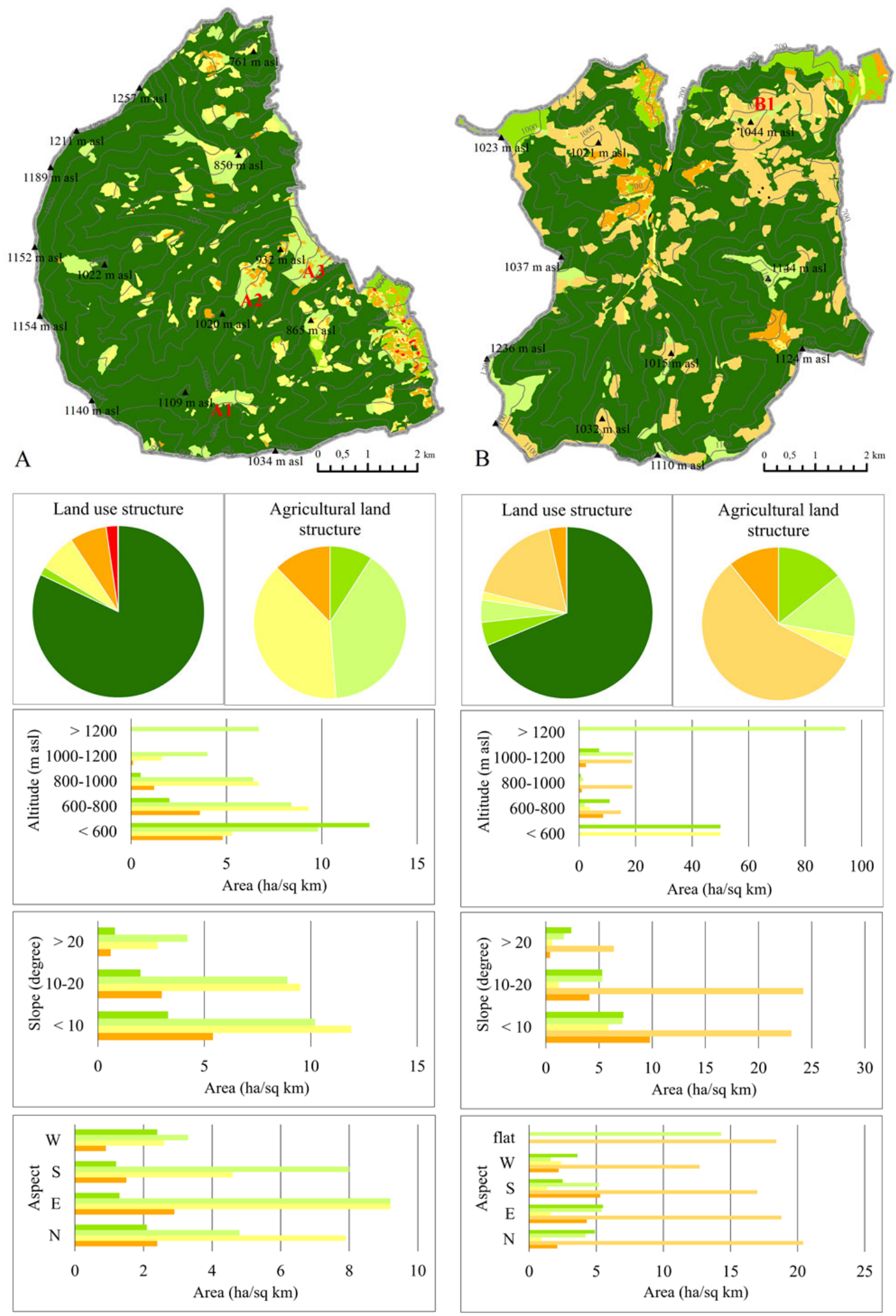

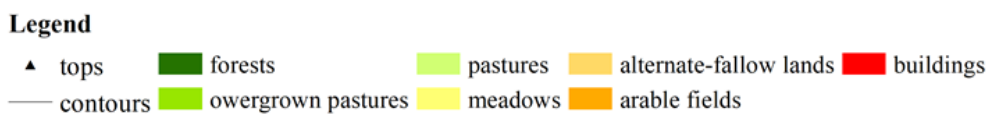

Fig. 3 Land use and agricultural land structure in 1848: the Barania Góra Range (A), the Wielka Racza Range (B). A1, A2, A3 and B1 - location of glades with field studies and LiDAR analyses. 


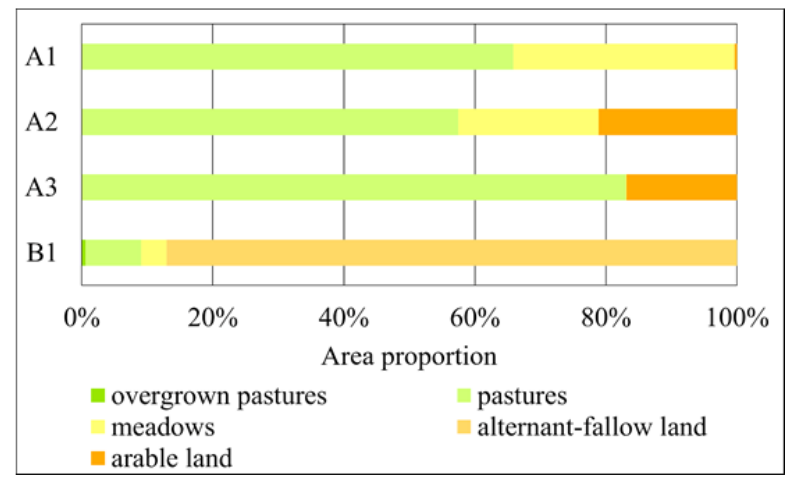

Fig. 4 Agricultural land structure in selected glades in 1848: A1 - Radziechowska, A2 - Ostre, A3 - Slopes of Ostre, B1 - Praszywka.

relationship was reversed, with a higher percentage of arable fields among plots without stone mounds (2/12, 17\%) compared to the percentage of arable fields among plots without stone mounds (49/77, 64\%). The median plot area was noticeably higher in the plots with stone mounds, as compared to the plots without stone mounds in all three regions (Fig. 7, middle panels). Additionally, the median plot area was higher for the arable fields, as compared to other plot types, especially in the B1 region (Fig. 7, lower panels).

The relationships between the test area, stone mounds and plot area suggest that the relationship between one of the predictors and the plot type may depend on the values of other predictor(s) (i.e., the predictors may interact). To determine which interactions are essential to adequately model the probability of a plot being an arable field, nine models with different combinations of main effects and interactions were matched to the data. The simplest model with the lowest LOOIC value consisted of an interaction of the test area and stone mounds and the main effect of the plot area (Appendix 1). This means that the relationship between stone mounds and plot type varies between test areas, whereas the relationship between plot area and plot type may be assumed to be the same for all test areas and plots with and without stone mounds.

Summary of the best fitting Bayesian logistic regression is presented in Table 2. The main effect of the plot area is straightforward: the probability of a plot being a field increases as the plot area increases (Fig. 8, left panel). The regression coefficients of the stone mounds and test area reflect sum-to-zero contrast coding and are not of direct interest, especially in the presence of credible interaction between the two predictors. To investigate the
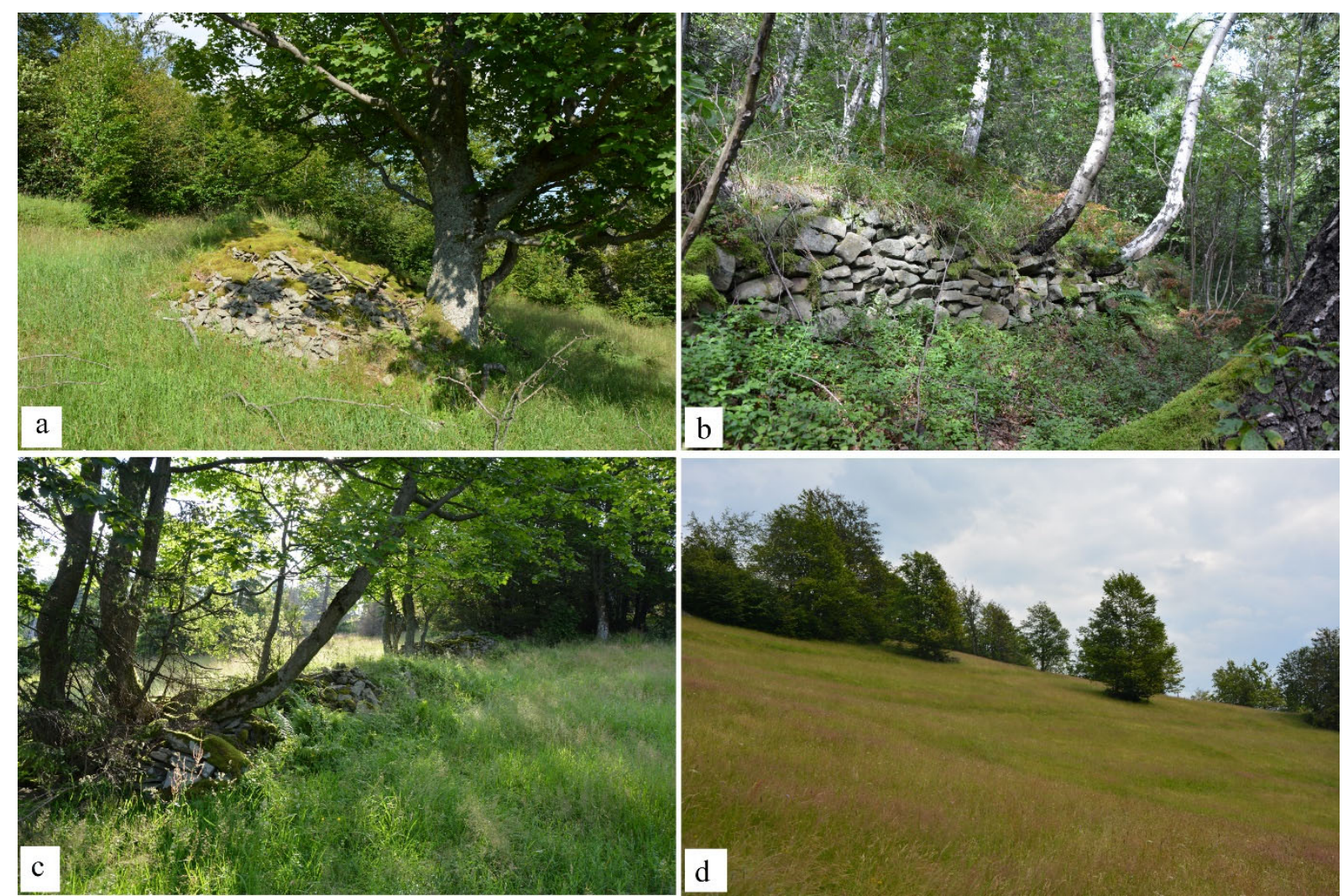

Fig. 5 Anthropogenic terrain forms: a) stone mound, b) stone wall, c) lynchet, d) terraces. 


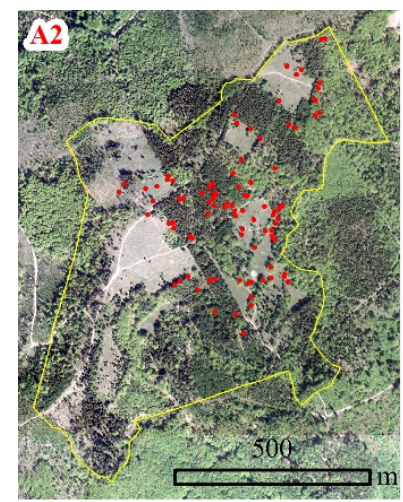

Legend

- stone mounds
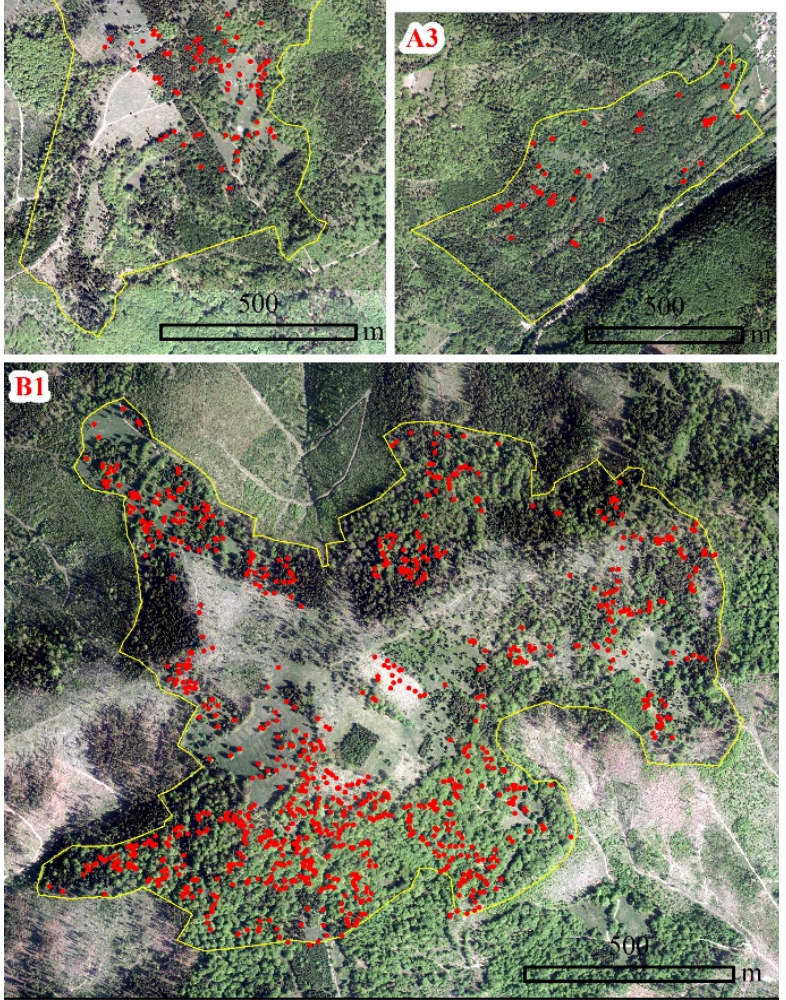

Fig. 6 Location of stone mounds (so called krudy).

interaction, a post hoc analysis was conducted in which the odds of a piece of land being a field were compared between plots with and without stone mounds, separately for each test area (Table 2, posthoc section). Additionally, the posterior conditional probabilities of a plot being an arable field as a function of the presence of stone mounds and test area are presented in Fig. 8 (right panel). In the A2 test area, plot type probability was not credibly related to the presence of stone mounds. In the B1 test area, the chances of a plot being an arable field were credibly higher for the plots with stone mounds, as compared to the plots without stone mounds. In the A3 test area, however, the chances of a plot being an arable field were credibly lower for the plots with stone mounds, as compared to the plots without stone mounds.

There are three types of linear anthropogenic terrain forms: lynchets, terraces and stone walls. Lynchets often have the form of stone walls. They are located in three out of the four tested areas (Fig. 9). They do not occur in A1 as there was only one small plot used as an arable field. In A2, lynchets and
Table 2 Results of the Bayesian logistic regression with land type as dependent variable

\begin{tabular}{|c|c|c|c|c|}
\hline \multicolumn{5}{|l|}{ Model coefficients } \\
\hline Land type & \multirow[b]{2}{*}{$\beta$} & \multirow[b]{2}{*}{ SE } & \multicolumn{2}{|c|}{$95 \% \mathrm{CI}$} \\
\hline $\begin{array}{l}\text { Arable fields (1) vs. } \\
\text { Other (o) }\end{array}$ & & & $2.5 \%$ & $97.5 \%$ \\
\hline Intercept & -0.47 & 0.18 & -0.86 & -0.12 \\
\hline Test area[1] & -0.41 & 0.23 & -0.87 & 0.03 \\
\hline Test area[2] & 0.72 & 0.21 & 0.32 & 1.17 \\
\hline Stone mounds & 0.35 & 0.21 & -0.03 & 0.79 \\
\hline Plot area & 0.74 & 0.17 & 0.43 & 1.1 \\
\hline $\begin{array}{l}\text { Test area[1]:Stone } \\
\text { mounds }\end{array}$ & -0.51 & 0.23 & -0.97 & -0.05 \\
\hline $\begin{array}{l}\text { Test area[2]:Stone } \\
\text { mounds }\end{array}$ & -0.96 & 0.22 & -1.42 & -0.57 \\
\hline \multicolumn{5}{|l|}{ Post-hoc } \\
\hline Stone mounds & Test area & OR & $2.5 \%$ & $97.5 \%$ \\
\hline \multirow{3}{*}{ Present / Absent } & A2 & 1.37 & 0.39 & 3.03 \\
\hline & A3 & 0.03 & 0.00 & 0.12 \\
\hline & $\mathrm{B} 1$ & $3 \cdot 34$ & 1.12 & 6.65 \\
\hline Prediction accuracy & $71 \%$ & & & \\
\hline
\end{tabular}

Notes: $\beta$ - regression weight on the logit scale, SE standard error of $\beta, 2.5 \%$ \& $97.5 \%$ - upper and lower bounds of the $95 \%$ credible interval. OR - odds ratio; for the OR to be statistically credible the 95\% CI should exclude one.

Plot area was entered after $\log$ and $\mathrm{Z}$ transformations and stone mounds and region were coded with sum-tozero contrasts.

terraces occur mainly in plots that were used as arable fields in 1848. There are only few linear forms that occur in plots that were meadows in 1848. In A3, much more linear forms occur outside arable fields distinguished on the map from 1848. What is more, they have the form of stone walls that do not occur in other test areas. The highest number of linear forms occur in B1. They are located solely in plots that were used as alternate-fallow land. However, not every plot of this type has linear terrain forms.

\section{Discussion}

\subsection{Land use reconstruction}

The degree of transformation of the environment connected with land cultivation in the Carpathians in the 19th century could be greater than the image visible on cadastral maps from 1848 . The results show that stone mounds connected with land cultivation also occur in plots that were not utilised as arable fields in 1848. This location of stone mounds may indicate that a particular plot used as a pasture or meadow in 1848 could have been used as an arable 
field before or after that year. This is connected with the fact that stone mounds are terrain forms typical of arable fields (Wolski 2016). Thus, the range of arable fields could be greater than that presented in the cadastral map. However, the location of stone mounds on a meadow or pasture may also result from the deposition of stones on the plot border. As a result, these forms could be located on an adjacent plot used in a way other than land cultivation, so as not to reduce the cultivation area (Latocha et al. 2019). On the other hand, the analysis of the location of stone mounds indicates that such a situation was not frequent in the study area. This may be associated with the different ownership of the neighbouring plots
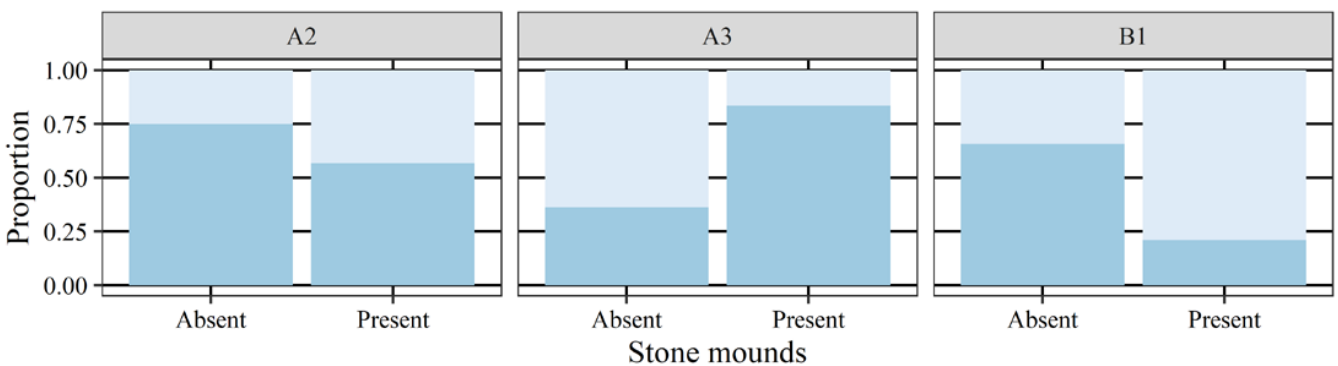

Plot type

Arable

fields

Other
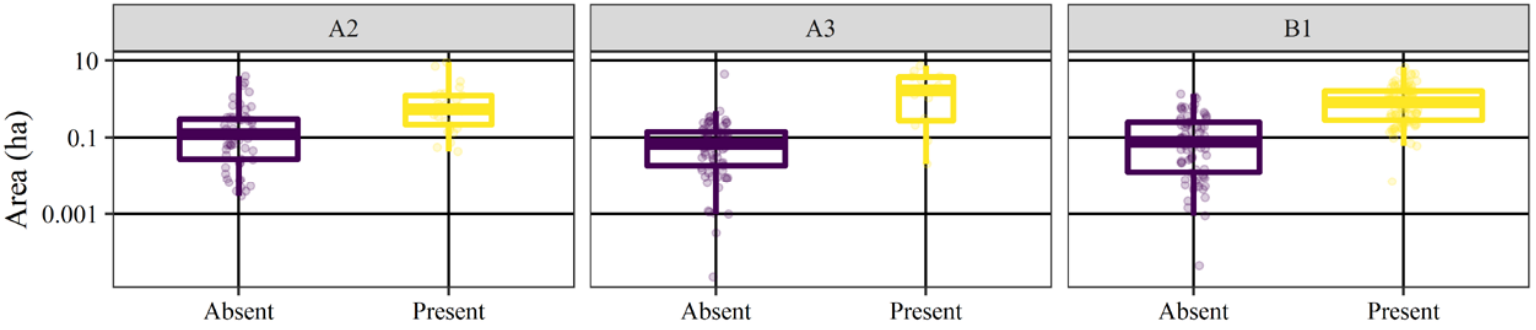

Stone mounds
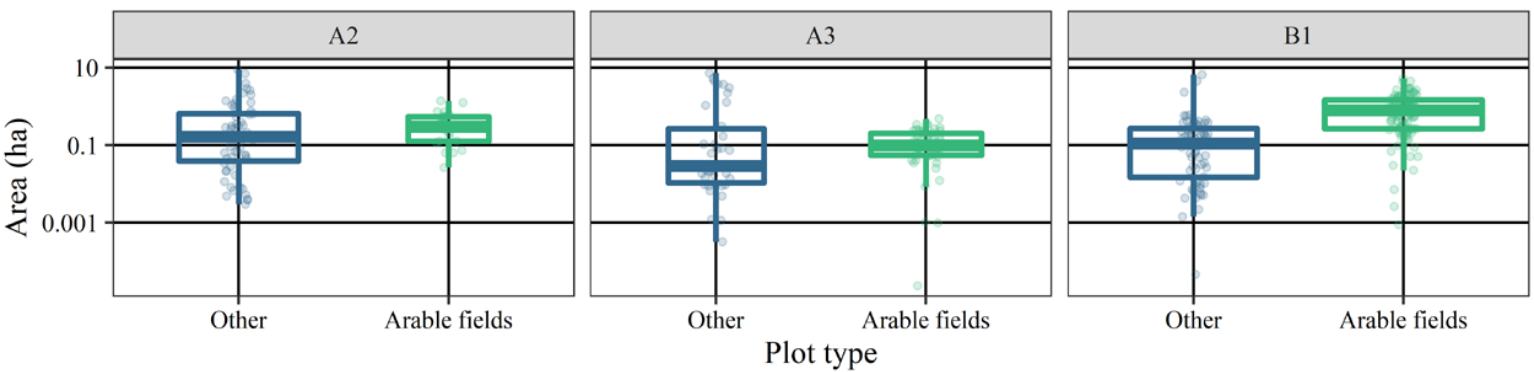

Fig. 7 Relationships between plot type, plot area and stone mounds in each test area. Lower and upper boundaries of the box are first and third quartile, respectively. Bolded horizontal line in the middle of the box shows the median.
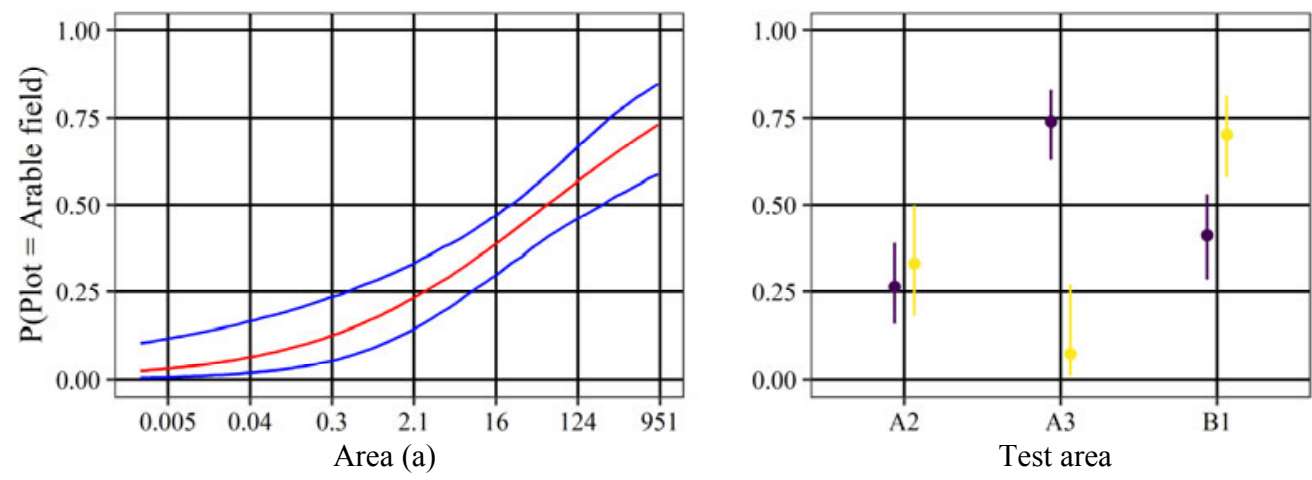

Stone mounds

- Absent

- Present

Fig. 8 Conditional effects. Left panel: mean posterior probability of a plot being an arable field as a function of plot area (red line). The thin blue lines show a lower and upper bound of a 95\% credible interval. Right panel: mean posterior probability of a plot being an arable field (points) as a function of test area and the presence of stone mounds. The vertical lines show $95 \%$ credible intervals. 
and the lack of consent to deposit stones.

While in the case of the A2 and B1 test areas, plots with stone mounds were more often arable lands in 1848 than plots without stone mounds $(79 \%$ and $43 \%$, respectively), this relationship was reserved in the A3 test area. The inventory of terrain forms in this area indicates that numerous stone walls were placed along the plot borders. Therefore, it can be concluded that, in this area, the stones from the arable fields were deposited mainly in the form of walls, not mounds. These forms are much more numerous in the A3 area than stone mounds. Furthermore, in these areas, far more linear forms occur outside arable fields distinguished on the map from 1848. This shows that the range of arable fields here could be much wider than presented on the cadastral maps. The location of this area could also confirm this statement. Among all the test areas, the location of A3 is the nearest to villages and simultaneously at the lowest altitudes. This, despite the steep slopes, makes this area the most suitable for land cultivation from all the analysed test areas (proximity to village's buildings and a dense network of relatively wellmaintained roads facilitating access to plots) (Jabs and Affek 2019).

It should also be noted that, according to the cadastral map, one plot used as an arable field was also located in the A1 test area. However, the remains of land cultivation have not been inventoried in this area. This could be for two reasons. Firstly, the land
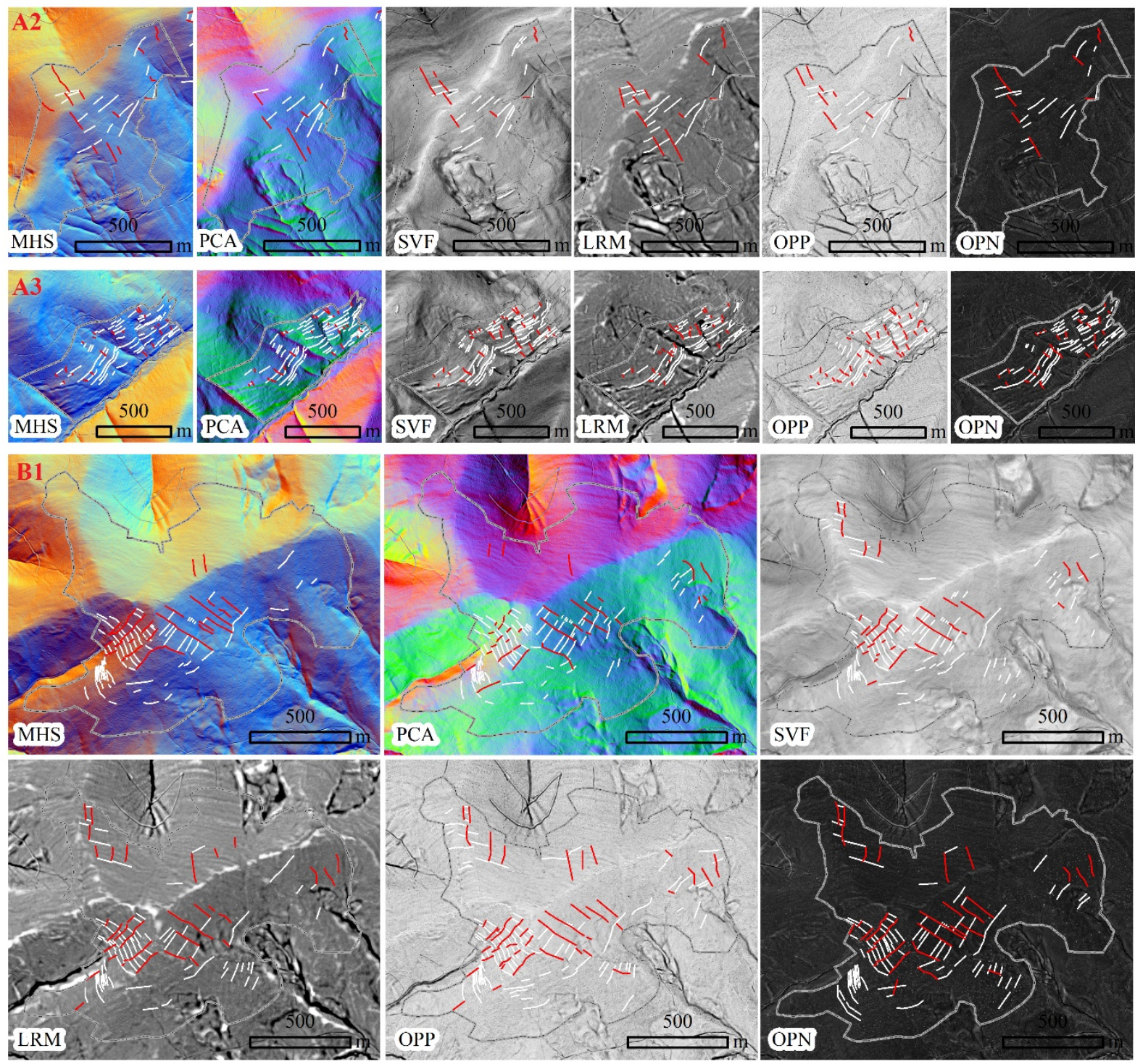

Fig. 9 Linear anthropogenic terrain forms connected with former agricultural activity: lynchets (red lines) and terraces or stone walls (white lines). For the meaning of the abbreviation, see Fig. 2. 
cultivation on this plot may have been carried out for too short a period. Thus, terrain forms connected with this activity were not developed. Secondly, this part of the test area is now covered with forest that may mask small landforms. As was indicated above, not all existing terrain forms can be clearly identified based on ALS and field studies. Due to secondary forest succession in abandoned glades, some forms are masked by vegetation, and reaching some parts of the glades is very difficult, sometimes even impossible. Mountain areas are particularly difficult to analyse, which is connected with the considerable relative heights and the presence of vegetation (Hyyppa et al. 2005; Stereńczak 2010). Low and dense vegetation was identified as problematic for ALS application in terrain form detection i.a. by Crow et al. (2007), Gallagher et al. (2008) and Banaszek (2020).

The problem of the inventory of terrain forms during fields studies mainly concerns linear objects because dense vegetation often makes it impossible to measure the entire form. It is often only possible to record information about the location of fragments of such forms, not about their length. ALS provides greater possibilities in the inventory of linear forms. Nevertheless, the effectiveness of interpretation of different DTM visualisation techniques differs, and no method enables the detection of all linear terrain forms (Doneus 2013). In turn, point forms are not difficult to inventory during field studies as they can most often be clearly defined. However, they are difficult to identify unequivocally from ALS data. Hence, it should be emphasised that the inventories based on ALS data and field studies are complementary (Affek 2014). This difference in the possibilities of the inventory of terrain forms influenced the methods of analysis used in this paper. Point terrain forms that were detected with a high level of accuracy were analysed using statistical methods, whereas linear terrain forms, which are difficult to detect and measure unequivocally, were analysed only in a descriptive way. A different treatment of the point and linear terrain forms inventoried based on ALS was also used by Kiarszysz and Banaszek (2017).

As there is no certainty that all existing remnants of human activity could be inventoried, it is impossible to reconstruct the former land use clearly. Some of the forms may have been destroyed (e.g., due to obtaining stone material as a building material) (Latocha et al. 2019). However, such situations have been observed sporadically in the test areas and are related to the adaptation of old sheds for recreational purposes in the A2 test area. Since it is a rare phenomenon in the study area, it has no significant impact on the results.

The conducted statistical analysis also allowed the relationship between the occurrence of the stone mounds, the plots utilised as arable fields in 1848, and the plot's size to be established. It was found that the median area of the arable fields was noticeably higher in the plots with stone mounds than in the plots without stone mounds. Additionally, the median of the field area was higher for the arable fields than for other land types. This issue was not the aim of the study, but the obtained results open up further possibilities of verifying the content of cadastral maps and may constitute the subject of further research.

\subsection{Land use suitability}

The analysis of the land use structure based on the cadastral map allows us to state that this structure was far from a suitable state in the study area in 1848 (Kopeć 2000). Although agricultural land was primarily located in areas with optimal natural conditions, along with the exhausting of favourable areas, less and less convenient areas were used. These were characterised by more steep slopes located in the higher parts of the mountains. The Barania Góra range was less managed by humans than the Wielka Racza range. Several factors could have influenced this. Firstly, it could have been caused by a morphological threshold between the Silesian Beskids and the Żywiec Basin. This threshold has always conditioned land utilisation and is still a communication barrier (Sobala et al. 2017). Secondly, the vast Żywiec Basin located in the vicinity of the Silesian Beskids is characterised by relatively good conditions for agricultural development. Thus, it met the inhabitants needs. In turn, the Wielka Racza range was more accessible to human activity. Simultaneously, in its vicinity, there are valleys of riverheads where the areas suitable for agricultural land use are much smaller than in the Żywiec Basin. As a result, the expansion of farmland on the slopes was more significant than in the Barania Góra range. In this area, it was common to use land in an alternate-fallow system. This system consisted of burning a tree on glades felled in winter and then seeding winter rye harvested for three consecutive 
years. After this period, decayed stumps were dug up and burned to recultivate the soil. After the soil was overcropped again, clearings were left fallow and used as pasture until they were overgrown with bushes again. After this stage, the whole cycle was repeated, starting again with burning the bushes (KopczyńskaJaworska 1967). This system of land use can be described as a human adaptation to harsh environmental conditions. It made land cultivation possible.

The scarcity of land available for settlement, which resulted in the overpopulation of these areas, was one of the main driving factors contributing to the formation of the land use structure in the 19th century in the whole Carpathians. Since that time, changes in the land use structure have resulted from a combination of many man-related factors, including socio-economic changes (Kroczak et al. 2018). Relationships between land use and relief characteristics have been studied, e.g., by Štych (2011), Faltan et al. (2011), and Zgłobicki and BaranZgłobicka (2012). A decrease in arable land, regardless of natural conditions for agricultural development, indicates that natural factors (slope gradient, elevation) are less critical than humanrelated ones (Kroczak et al. 2018).

Using ALS and field studies in historical land use research provides new insight on that issue. Similar conclusions were drawn by Stereńczak et al. (2020). They proved, based on ALS, that the extent of the area and the impact of human activities in the Polish part of the Białowieża Forest was substantially more significant than previously believed. Nevertheless, analyses of terrain forms in relation to historical land use are rarely documented in the literature (Pietrzak 2002; Kroczak 2010; Kroczak et al. 2016). Affek (2015) also claims that airborne laser scanning gave a unique possibility to reveal a historic Carpathian landscape in abandoned areas. Terrain forms from the 19th century appeared to be very well preserved. This author emphasises that it is also relatively easy to distinguish old forms from modern ones, which are rather sparse and of a different shape.

As far as minimal forest range in the Carpathians is concerned, Austrian cadastral maps probably show the highest deforestation range. Detailed research on that issue was conducted by Troll and Ostafin (2016). They proved that, from 1845 to 1898 , the forest cover in Zawoja (Western Carpathians) was stable at its lowest level in the whole temporal sequence.
Stabilisation of the forest area in the second half of the 19th century was quite common in the Polish Carpathians (Fierich 1950; Konias 2000; Kozak 2010). The phase of deforestation up to the 19th century was associated above all with the late formation of the villages and their spread to the higher and less accessible parts of the mountains. The phase of stabilisation lasted at least until the end of the 19th century; however, it might well have extended until World War II, which preceded the stage of forest cover increase which has continued until today (Troll and Ostafin 2016).

Although detailed studies were conducted in only four test areas, the results provide new insight into land use structure in the Western Carpathians in the 19th century. It is essential that the test areas differ in terms of land use, reflecting the different ways of land use in higher parts of the mountains in the Western Carpathians. Secondly, they are located at different altitudes (in the range of 550-1050m asl.), typical of most parts of the Western Carpathians. The Silesian and Żywiec-Kysuce Beskids are similar to other mountain ranges of the Western Carpathians in terms of the main features of the natural environment (altitudes, plant and climate zonation). A significant limitation in the possibility of carrying out the study was that the cadastral maps have not been preserved for a large area of the study area. In turn, this creates the need for alternative methods of study on land-use changes.

\section{Conclusions}

The degree of transformation of the environment connected with land cultivation in the Carpathians in the 19th century could be greater than the image visible on cadastral maps from 1848. This is connected with the fact that archival maps refer only to a single time section in the past and do not show information on land use between particular time sections presented on consecutive maps. It seems to be crucial while concluding about land use changes and the maximal level of human impact on the environment.

It must be emphasised that it is impossible to determine the historical structure of land use precisely based on anthropogenic terrain forms. Nevertheless, this research gives new insights into the land use structure in the Western Carpathians in the 
19th century compared to data obtained from archival maps. While determining the historical land use, all forms typical of land cultivation should be regarded simultaneously. The inventory of terrain forms in the study area indicates that the stones from the arable fields were deposited in the form of walls or mounds, depending on location.

Not all existing terrain forms can be clearly identified based on ALS and field studies. These two methods are complementary. The problem of the inventory of terrain forms during fields studies mainly concerns linear objects because dense vegetation often makes it impossible to measure the entire form. By contrast, ALS provides greater possibilities in the inventory of linear forms. Nevertheless, the detection of all linear terrain forms is also impossible. In turn, point forms are not difficult to inventory during field studies as they can most often be clearly defined. However, they are difficult to identify unequivocally from ALS data.

The historical land use analysis based on the occurrence of anthropogenic terrain forms using ALS and field studies allows the content of historical maps to be verified, which is postulated by the researchers. However, it should be noted that this is only one of many possible methods of verifying the content of archival maps. Comprehensive research should also include other methods, such as soil or botanical research, among others. Anthropogenic terrain form inventory can also be used for land use assessment

\section{Reference}

Affek A (2013) Georeferencing of historical maps using GIS, as exemplified by the Austrian Military Surveys of Galicia. Geographia Polonica 86: 375-390.

Affek A (2014) Airborne laser scanning (ALS) in terrain modelling - new opportunities and pitfalls. Problems of Landscape Ecology 37: 217-236. (In Polish)

Affek A (2015) Exploring past Carpathian landscape: the application of LiDAR and archival cadastral maps. Archaeologia Polona 53: 243-248

Affek A (2016) Hidden cultural heritage in the abandoned landscape - identification and interpretation using airborne LiDAR. Geographia Polonica 89: 411-414.

Agnoletti M (2007) The degradation of traditional landscape in a mountain area of Tuscany during the 19th and 2oth centuries: Implications for biodiversity and sustainable management. Forest Ecol Manag 249: 5-17. https://doi.org/10.1016/j.foreco.2007.05.032

Bakker MM, Govers G, Jones RA, Rounsevell MDA (2007) The effect of soil erosion on Europe's crop yields. Ecosystems 10: 1209-1219. https://doi.org/10.1007/s10021-007-9090-3

Banaszek $€$ (2020) It takes all kinds of trees to make a forest. Using historic maps and forestry data to inform airborne laser scanning based archaeological prospection in woodland. when historical maps have not been preserved or when available maps do not present land use in detail.

\section{Acknowledgements}

The research reported in this manuscript was funded by the National Science Centre Poland (Grant number 2019/03/X/ST10/o0775). The author would like to thank Kamil Fulawka from Pogotowie Statystyczne for a support in data analysis and Dr. Katarzyna Pukowiec-Kurda for technical support. I thank four anonymous reviewers for their comments, which helped to improve the manuscript.

Electronic supplementary material: Supplementary material (Appendix 1) is available in the online version of this article at https://doi.org/10.1007/s11629-021-6680-Z

Open Access This article is distributed under the terms of the Creative Commons Attribution 4.0 International License

(http://creativecommons.org/licenses/by/4.0/), which permits unrestricted use, distribution, and reproduction in any medium, provided you give appropriate credit to the original author(s) and the source, provide a link to the Creative Commons license, and indicate if changes were made.

Archaeol Prospect 27: 377-392.

https://doi.org/10.1002/arp.1780

Baumann M, Kuemmerle T, Elbakidze M, Ozdogan M, Radeloff VC,.; Keuler NS, Prishchepov AV, Kruhlov I, Hostert P (2011) Patterns and drivers of post-socialist farmland abandonment in Western Ukraine. Land Use Policy 28: 552-562. https://doi.org/10.1016/j.landusepol.2010.11.003

Bender O, Boehmer HJ, Jens D, Schumacher KP (2005) Using GIS to analyse long-term cultural landscape change in Southern Germany. Landscape Urban Planning 70: 111-125. https://doi.org/10.1016/j.landurbplan.2003.10.008

Bičík I, Jeleček L, Štěpánek V (2001) Land-use changes and their social driving forces in Czechia in the 19th and 20th centuries. Land Use Policy 18: 65-73. https://doi.org/10.1016/So264-8377(oo)ooo47-8

Biró M, Czúcz B, Horváth F, Révész A, Csatári B, Molnár Z. (2012) Drivers of grassland loss in Hungary during the postsocialist transformation (1987-1999). Landscape Ecol 28: 789-803. https://doi.org/10.1007/s10980-012-9818-o

Boucher Y, Grondin P, Auger I (2014) Land use history (18402005) and physiography as determinants of southern boreal forests. Landscape Ecol 29: 437-450.

https://doi.org/10.1007/s10980-013-9974-x 
Broda J (1956) Forest management in the Żywiec region until the end of the 18th century. Wydawnictwo Naukowe PWN, Warszawa, Poland (In Polish)

Brus J, Pechanec V, Machar I (2018) Depiction of uncertainty in the visually interpreted land cover data. Ecol Inform 47, 10-13. https://doi.org/10.1016/j.ecoinf.2017.10.015

Bucala-Hrabia A (2017) Long-term impact of socio-economic changes on agricultural land use in the Polish Carpathians. Land Use Policy 64: 391-404. https://doi.org/10.1016/j.landusepol.2017.03.013

Bürkner PC (2017) brms: An R package for Bayesian multilevel models using Stan. J Stat Softw 80: 1-28 https://doi.org/10.18637/jss.vo8o.io1

Crow P, Benham S, Devereux BJ, Amable GS (2007) Woodland vegetation and its implications for archaeological survey using LiDAR. Forestry 80: 241-52. https://doi.org/10.1093/forestry/cpmo18

DeFries RS, Foley JA, Asner GP (2004) Land - use choices: balancing human needs and ecosystem function. Front Ecol Environ 2: 249-257. https://doi.org/10.1890/1540-9295(200 4)002[0249:LCBHNA]2.0.CO;2

Dolejš M, Forejt M (2019) Franziscean cadastre in landscape structure research: A systematic review. Quaestiones Geographicae 38: 131-144. https://doi.org/10.2478/quageo-2019-0013

Doneus M (2013) Openness as Visualization Technique for Interpretative Mapping of Airborne Lidar Derived Digital Terrain Models. Remote Sensing 5: 6427-6442. https://doi.org/10.3390/rs5126427

Duchoslav M (2002) Flora and vegetation of stony walls in East Bohemia (Czech Republic). Preslia 74: 1-25

Duma P, Latocha A, Łuczak A, Piekalski J (2020) Stone Walls as a Characteristic Feature of the Cultural Landscape of the Izera Mountains, southwestern Poland. Int J Hist Archaeol 24: 2243. https://doi.org/10.1007/s10761-019-00501-2

Faltan V, Bánovský M, Blažek, M (2011) Evaluation of land cover changes after extraordinary windstorm by using the land cover metrics: a case study on the high Tatras foothill. Geografie 116: 156-171.

https://doi.org/10.37040/geografie2011116020156

FAO (2013) Mountain Farming is Family Farming. A contribution from mountain areas to the International Year of Family Farming 2014.

(http://www.fao.org/docrep/o19/i348oe/i348oe.pdf, accessed on 2021-01-11)

Feranec J. Ot'ahel' J (2008) Land cover changes in Slovakia in the period 1970-200o. Geogr. Časopis 60: 113-128.

Feucht R (2008) Flächenangaben im osterreichischen Kataster. Technische Universität Wien. (ftp://ftp.geoinfo.tuwien.ac. at/other/DA Feucht.pdf, accessed on 2021-01-07)

Fierich J (1950) Agricultural cultures, changes and harvesting in the Josephine cadastre 1785/7. Rocznik Dziejów Społecznych i Gospodarczych 12: 25-66. (In Polish)

Forejt M, Dolejš M, Raška P (2018) How reliable is my historical land-use reconstruction? Assessing uncertainties in old cadastral maps. Ecol Indic 94: 237-245. https://doi.org/10.1016/j.ecolind.2018.06.053

Forejt M, Dolejš M, Zacharová J, Raška P (2020) Quantifying inconsistencies in old cadastral maps and their impact on land-use reconstructions. Journal of Land Use Science 15: 570-584. https://doi.org/10.1080/1747423X.2020.1765427

Gallagher JM. Josephs RL (2008). Using LiDAR to Detect Cultural Resources in a Forest Environment: an Example from Isle Royale National Park, Michigan, USA. Archaeol Prosp 15: 187-206. https://doi.org/10.1002/arp.333

Hamre N, Domaas ST, Austad I, Rydgren K (2007) Land-cover and structural changes in a western Norwegian cultural landscape since 1865 , based on an old cadastral map and a field survey. Landscape Ecol 22: 1563-1574. https://doi.org/10.1007/s10980-007-9154-y

Harvey F, Kaim D, Gajda A (2014) Analysis of historical change using cadastral materials in the Carpathian foothills.
European Journal of Geography 5: 6-21.

Hollingsworth L, Collier MJ (2020) Ground flora of field boundary dry stone walls in the Burren, Ireland. British \& Irish Botany 2(4): 352-376.

https://doi.org/10.33928/bib.2020.02.352

Hyyppä H, Yu X, Hyyppä J, Kaartinen H, Kaasalainen S, Honkovaara E, Ronnholm P (2005) Factors affecting quality of DTM generation in forested areas. ISPRS Workshop "Laser scanning 2005". Enschede, Holand.

Istvánovics V (2009) Eutrophication of lakes and reservoirs. In: Likens GE (eds.), Encyclopedia of Inland Waters. London, Great Britain. Academic Press. pp. 157-165. https://doi.org/10.1016/B978-012370626-3.00141-1

Jabs Z, Affek A (2019) The agricultural accessibility of the Beskid Mountains. Przegląd Geograficzny 91: 97-111. (In Polish) https://doi.org/10.7163/PrzG.2019.2.6

Jawor G (2000) Wallachian law settlements and theirs inhabitants of Red Ruthenia in the late Middle Ages. Wydawnictwo Uniwersytetu Marii Curie-Skłodowskiej, Lublin, Poland. (In Polish)

Johnson KM, Ouimet WB (2016) Physical properties and spatial controls of stone walls in the northeastern USA: Implications for Anthropocene studies of 17th to early 2oth century agriculture. Anthropocene 15: 22-36.

https://doi.org/10.1016/j.ancene.2016.07.001

Kaim D, Kozak J, Ostafin K, Dobosz M, Ostapowicz K, Koleck N, Gimmi, U (2014) Uncertainty in Historical Land-Use Reconstructions with Topographic Maps. Quaestiones Geographicae 33: 55-63.

https://doi.org/10.2478/quageo-2014-0029

Kain R, Baigent E (1994) The Cadastral Map in the Service of the State: A History of Property Mapping. American History Review 99: 1645-1646.

https://doi.org/10.1086/ahr/99.5.1645

Kiarszysz G, Banaszek $Ł$ (2017) To identify and understand. A comparison of selected ALS visualization techniques used in archeorogical interpretative mapping. Folia Praehistorica Posnaniensia 22: 233-270. (In Polish)

https://doi.org/10.14746/fpp.2017.22.11

Kijowska-Strugala M, Bucala-Hrabia A, Demczuk P (2018) Long-term impact of land use changes on soil erosion in an agricultural catchment (the Western Polish Carpathians). Land Degrad Dev 29: 1-14. https://doi.org/10.1002/ldr.2936

Kirkby MJ, Bracken LJ (2009) Gully processes and gully dynamics. Earth Surf Proc Land 34: 1841-1851. https://doi.org/10.1002/esp.1866

Kokalj Z̆, Hesse R (2017) Airborne laser scanning raster data visualization. A Guide to Good Practice. Institute of Anthropological and Spatial Studies. Ljubljana, Slovenia. https://doi.org/10.3986/9789612549848

Kondracki J (1989) Karpaty, 2nd edn. Wydawnictwa Szkolne i Pedagogiczne, Warszawa.

Konias A (2000) Topographic cartography of Teschin Silesia and Austrian Monarchy from the second part of the 18th to the beginning of the 2oth centuries. Wydawnictwo Uniwersytetu Sląskiego, Katowice, Poland. p 260. (In Polish)

Kopczyńska-Jaworska B (1967) Economic and social relations in the traditional culture of the Northern Carpathians Part I. Uniwersytet Łódzki, Łódź, Poland. (In Polish)

Kopeć S (2000) Criteria for delimitation of marginal mountain soils for excluding them from agricultural use. Problems of the Mountain Areas Development PAN 45: 3-15. (In Polish)

Kozak J (2004) Contemporary changes to the forest cover of the world's mountains. Przegląd Geograficzny 76: 307-326. (In Polish)

Kozak J. (2010) Forest Cover Changes and Their Drivers in the Polish Carpathian Mountains Since 180o. In: Nagendra H, Southworth J (eds.) Reforesting Landscapes. Landscape Series, vol 10. Springer, Dordrecht. pp. 253-273.

https://doi.org/10.1007/9781-4020-9656-3_11

Kozak J, Ostapowicz K, Bytnerowicz A, Wyżga B (2013) The 
Carpathian Mountains: challenges for the central and eastern European Landmark. In: Kozak J, Ostapowicz K, Bytnerowicz A, Wyżga B (eds.), The Carpathians: Integrating Nature and Society Towards Sustainability. Springer-Verlag, Berlin Heidelberg. pp 1-12. https://doi.org/10.1007/978-3-642-12725-0_1.

Kozak J, Ziółkowska P, Vogt M, et al. (2018) Forest-cover increase does not trigger forest-fragmentation decrease: case study from the Polish Carpathians. Sustainability 10: 1472. https://doi.org/10.3390/su10051472

Kroczak R (2010) Geomorphological and hydrological effects of unmetalled road network functioning on the example of Ciezkowickie Foothills. Geographical Studies PAS 225: 138. (In Polish)

Kroczak R, Bryndal T, Bucala A, Fidelus J (2016) The development, temporal evolution and environmental influence of an unpaved road network on mountain terrain-an example from the Carpathian Mts. (Poland). Environ Earth Sci 75: 114. https://doi.org/10.1007/s12665-015-5055-6

Kroczak R, Fidelus-Orzechowska J, Bucała-Hrabia A, Bryndat T (2018) Land use and land cover changes in small Carpathian catchments between the mid-19th and early 21st centuries and their record on the land surface. J Mt Sci 15: 2561-2578. https://doi.org/10.1007/s11629-018-5095-y

Kucsicsa G, Dumitrică C (2019) Spatial modelling of deforestation in Romanian Carpathian Mountains using GIS and Logistic Regression. J Mt Sci 16: 1005-1022. https://doi.org/10.1007/s11629-018-5053-8

Latocha A, Reczyńska K, Gradowski T, Swierkosz K (2019) Landscape memory in abandoned areas-physical and ecological perspectives (Central European mountains case study). Landscape Res 44: 600-613.

https://doi.org/10.1080/01426397.2018.1493446

Leyk S, Boesch R, Weibel R (2005) A conceptual framework for uncertainty investigation in map-based land cover change modeling. T GIS 9: 291-322. https://doi.org/10.1111/j.1467-9671.2005.00220.x

Machar I, Vozenilek V, Simon J, et al. (2017) Joining of the historical research and future prediction as a support tool for the assessment of management strategy for European beechdominated forests in protected areas. Nat Conserv 22: 51-78. https://doi.org/10.3897/natureconservation.22.12902

Manenti R (2014) Dry stone walls favour biodiversity: a casestudy from the Apennines. Biodivers Conserv 23: 1879-1893. https://doi.org/10.1007/s10531-014-0691-9

Maras SS, Maras HH, Aktug B, et al. (2010) Typological error correction of GIS vector data. Int J Phys Sci 5 (5): 476-483. https://doi.org/10.5897/IJPS.9000598

Mather AS (1992) The forest transition. Area 24: 367-379.

Mather AS, Needle CL (1998) The forest transition: a theoretical basis. Area 30: 117-124.

Munteanu C, Kuemmerle T, Keulerd NS, et al. (2015) Legacies of 19th century land use shape contemporary forest cover. Global Environ Chang 34: 83-94. https://doi.org/10.1016/j.gloenvcha.2015.06.015

Myga-Piątek U (2015) Landscape memory - a record of history in space. Studia Geohistorica 3: 31-47. (In Polish)

Nieścioruk K (2013) Cartographic source materials and cartographic method of research in the past environment analyses. Bulletin of Geography. Socio-economic Series 22: 81-95. https://doi.org/10.2478/bog-2013-0033

Niu YJ, Zhu HM, Yang SW, et al. (2019) Overgrazing leads to soil cracking that later triggers the severe degradation of alpine meadows on the Tibetan Plateau. Land Degrad Dev 30: 1243-1257. https://doi.org/10.1002/ldr.3312

Pietrzak M (2002) The impact of land-use change on ground relief in the Wisnickie Foothills, southern Poland. Environmental Changes in the Carpathian Foothills 2. p 150. (In Polish)

Plit J (2006) Historical analysis as a source of information on natural environment. Problems of Landscape Ecology 16: 217-
226. (In Polish)

$\mathrm{R}$ Core Team (2020) R: A language and environment for statistical computing. R Foundation for Statistical Computing, Vienna, Austria.

https://www.R-project.org, accessed on 2021-01-07.

Sobala M (2018) Pasture landscape durability in the Beskid Mountains (Western Carpathians, Poland). Geographia Polonica 91: 197-215. https://doi.org/10.7163/GPol.0117

Sobala M, Rahmonov O (2020) The human impact on changes in the forest range of the Silesian Beskids (Western Carpathians). Resources 9: 141.

https://doi.org/10.3390/resources9120141

Sobala M, Rahmonov O, Myga-Piatek U (2017). Historical and contemporary forest ecosystem changes in the Beskid Mountains (southern Poland) between 1848 and 2014. iForest 10: 939-947. https://doi.org/10.3832/ifor2418-010

Stereńczak K (2010) Airborne Laser Scanner technology as a source of data for semi-automatic forest inventory. Sylwan 154: 88-99. (In Polish)

Stereńczak K, Zapłata R, Wójcik J, et al. (2020) ALS-based detection of past human activities in the Białowieża ForestNew evidence of unknown remains of past agricultural systems. Remote Sens 12:2657. https://doi.org/10.3390/rs12162657

Stych P (2011) Comparative analysis of the impact of slope inclination and altitude on long-term land use changes in Czechia. AUC Geographica 46: 71-76.

Tarolli P, Preti F, Romano N (2014) Terraced landscapes: From an old best practice to a potential hazard for soil degradation due to land abandonment. Anthropocene 6: 10-25. https://doi.org/10.1016/j.ancene.2014.03.002

Troll M, Ostafin K (2016) Use of late 18th and early 19th century cadastral data to estimate past forest cover change - a case study of Zawoja village. Prace Geograficzne 146: 31-49. https://doi.org/10.4467/20833113PG.16.016.5546

Vehtari A, Gelman A, Gabry J (2017) Practical Bayesian model evaluation using leave-one-out cross-validation and WAIC. Stat Comput 27: 1413-1432.

https://doi.org/10.1007/s11222-016-9696-4

Wolski J (2007) Transformations of the High Bieszczady Mountains rural landscape during the last 150 years. Geographical Studies PAS 214: 218. (In Polish)

Wolski J (2009) Consequences of the disappearance of human impact from mountainous areas - a discussion of "process vs. region" relationships as conceptualized on various scales. Przegląd Geograficzny 81: 47-73. (In Polish)

Wolski J (2012) Errors and uncertainty in digital mapping. Dissertation Commission of Cultural Landscape 16: 15-32. (In Polish)

Wolski J (2016) Anthropogenic forms of terrain relief as an evidence of past human activity. In: Wolski $J$ (ed.), Bojkowszczyzna Zachodnia - wczoraj, dziś i jutro part II. Monografie IGiPZ PAN 17, Warszawa, Poland. Instytut Geografii i Przestrzennego Zagospodarowania PAN. pp. 165205. (In Polish)

Thompson JR, Carpenter DN, Cogbill CV, Foster DF (2013) Four Centuries of Change in Northeastern United States Forests. Plose One 8: e72540. https://doi.org/10.1371/journal.pone.0072540

Wallin DO, Swanson FJ, Marks B (1994) Landscape Pattern Response to Changes in Pattern Generation Rules: Land - Use Legacies in Forestry. Ecological Applications 4: 569-580. https://doi.org/10.2307/1941958

Yang YY, Zhang SW, Yang JC, et al. (2014) A review of historical reconstruction methods of land use/land cover. J Geogr Sci 24: 746-766. https://doi.org/10.1007/s11442-014-1117-z

Zgłobicki W, Baran-Zgłobicka B (2012) Impact of loess relief on land use mosaic in SE Poland. Catena 96: 76-82. https://doi.org/10.1016/j.catena.2012.04.014 